\title{
Comparisons between the chemistry of phosphirenes and silirenes
}

\author{
François Mathey \\ Laboratoire de Chimie du Phosphore et des Métaux de Transition, DCPH, \\ Ecole Polytechnique, 91128 Palaiseau Cedex, France

\begin{abstract}
The syntheses and the structural, spectroscopic, and chemical properties of phosphirenes, phosphirene-transition metal complexes, and silirenes are discussed and compared. Close analogies are noted in the synthetic schemes and physico-chemical properties of the two types of three-membered rings.
\end{abstract}

\section{INTRODUCTION}

Currently, the chemistry of the unsaturated three-membered heterocycles $\mathrm{XC}_{2} \mathrm{R}_{2}$ can be considered as one of the most exciting area of heterocyclic chemistry. The interest in these species is derived from three main reasons : firstly, these cycles can serve to build a series of $2 \pi$-aromatic and $4 \pi$-antiaromatic structures; secondly, the properties of their intracyclic X-C bonds are very peculiar ( $\pi$-character, so-called "banana" shapes) ; thirdly, through ring-opening and ring-expansion, these cycles are ideal starting points for the synthesis of a wide range of other species. With the first-row heteroatoms, the search for these rings has met with a limited success except in the case of boron. The nitrogen and oxygen derivatives appear to be highly unstable. With the second-row heteroatoms, the search was more successful, especially in the cases of silicon and phosphorus. The corresponding silirenes and phosphirenes are the subject of this report.

\section{SYNTHESIS}

One of the basic schemes for the synthesis of silirenes involves, at least formally, the reaction of a silylene with a $C \equiv C$ triple bond. What is left open is the choice of the silylene precursor. Some examples are given in eq. 1-3.

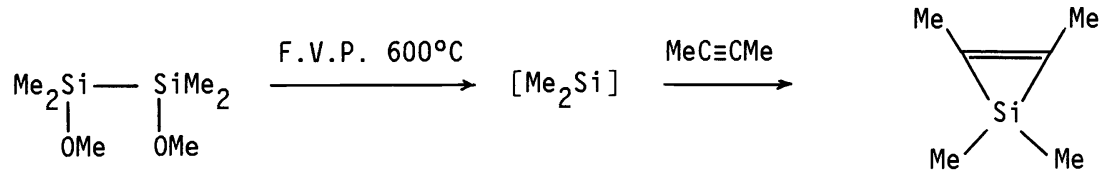

(1) (ref.1)

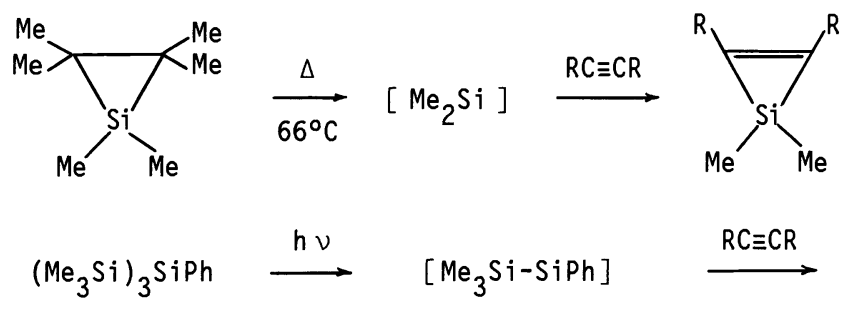

(2) (ref. 2, 3)<smiles>[R]C1C2C1([R])[Si]2([SiH2])[SiH3]</smiles>

(3) $($ ref.4)

It is striking to note that the only known access to phosphirenes involves the similar reactions of electr・n-deficient phosphorus species with alkynes. Once again, the choice of the precursors is left open (eq. 4-6) 


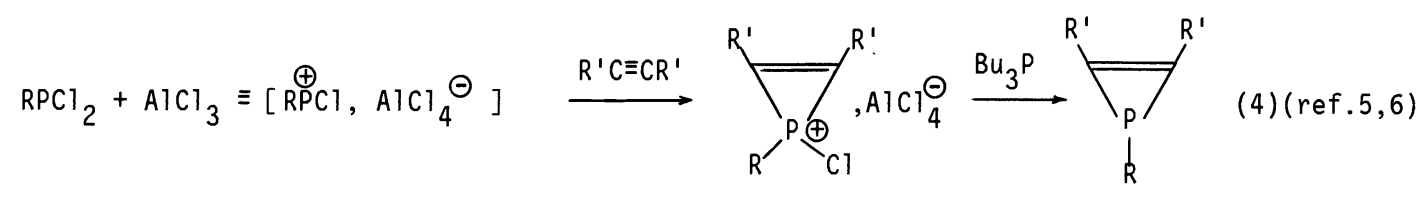

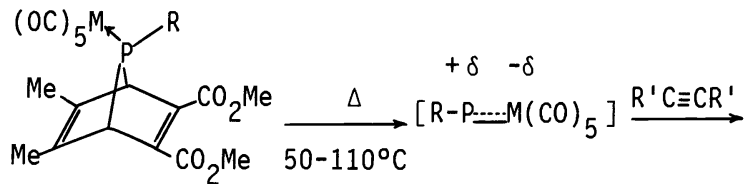

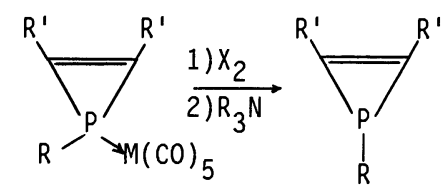

(5) $($ ref. 7,8$)$ $M=C r, M o, W$

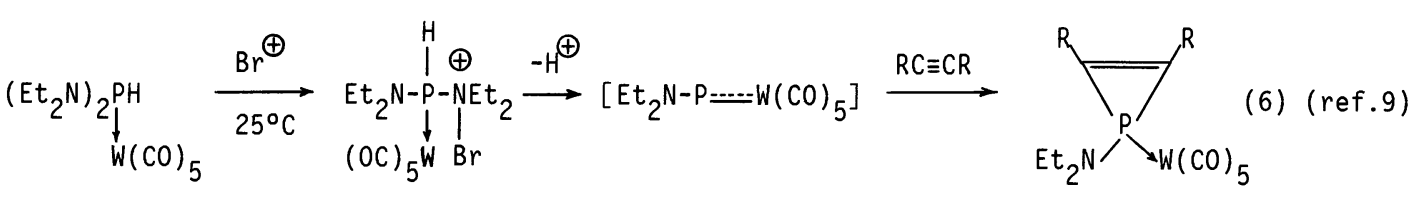

In the first case, the phosphenium ion is, in fact,strictly isoelectronic with a silylene. In the two other cases, the transient terminal phosphinidene complex may be compared to an organometallic silylene (see ref. 10) since the phosphorus atom bears a strong positive charge (ref. 11). An even more striking parallelism was observed in one case when a phosphirane-phosphirene interconversion was described in strict analogy with the silirene synthesis depicted in eq. 2 (eq. 7).

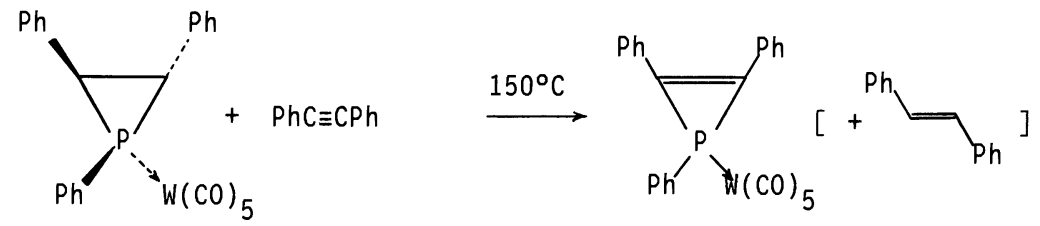

On the contrary, no phosphorus equivalent of the other established route to silirenes is known at the moment (eq. 8).<smiles>[R]C#[Si]([R])([R])[Si]S([R])([R])[Si]</smiles>

(8) (ref. 13-16)

\section{PHYSICOCHEMICAL PROPERTIES}

One silirene (ref. 17), one phosphirene (ref. 18) and one phosphirene P-complex (ref. 7) have been investigated by X-ray crystal structure analysis. The corresponding data are collected in Table 1. It immediately appears that, structurally speaking, phosphirene complexes are closer to silirenes than free phosphirenes. On the basis of two rather unsophisticated criteria $\underline{i}$.e. the difference between the lengths of the exocyclic and intracyclic $\mathrm{X}-\mathrm{C}$ bonds on one hand, and the length of the $\mathrm{C}=\mathrm{C}$ intracyclic bond on the other hand, it seems that electronic cyclic delocalization is higher in silirenes and phosphirene complexes than in free phosphirenes. Theoretical calculations on phosphirene (ref. 19) and its $\mathrm{P} \rightarrow \operatorname{Cr}(\mathrm{CO})_{5}$ complex (ref. 11) rationalize this finding. P-complexation stabilizes the phosphirene ring by suppressing the destabilizing $n \pi$ interaction between the lone pair at phosphorus and the $\pi$ bond. From a theoretical standpoint, phosphirene and silirene are built from interacting heteroatomic (X) and acetylenic subunits. In the case of phosphirene (ref. 19), the HOMO corresponds to a $n_{p}(P)-\pi_{1}(C \equiv C)$ and the next occupied level to a $p^{*}(P)+\pi_{2}^{*}(C \equiv C)$ combination. This orbital can be viewed as an asymetric combination of the two P-C "banana"bonds. It corresponds to an electronic transfer ( $\sigma$ delocalization) from $\mathrm{X}$ to the $\pi *(\mathrm{C} \equiv \mathrm{C}$ ) orbital and thus induces a lengthening of the $C=C$ bond (Fig. 1). A similar picture is observed in the case of silirene (ref. 20). The role of the (3d-2p) $\pi$ two-electron stabilizing interaction appears to be minimal contrary to earlier predictions (ref. 21). 


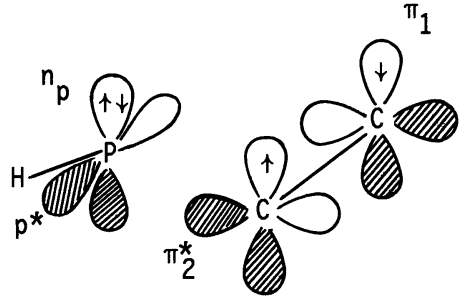

Fig. 1. Interactions between a phosphinidene and a $C \equiv C$ triple bond

From a spectroscopic standpoint, the most fascinating features of these two rings are the remarkably large upfield shifts of the ${ }^{29} \mathrm{Si}$ and $31_{\mathrm{P}}$ resonances observed when comparing silirenes and phosphirenes on one hand, and "normal" silanes and phosphines on the other hand. The chemical shifts are in the range -87 to $-106 \mathrm{ppm}$ (vs $\mathrm{Me}_{4} \mathrm{Si}$ ) for silirenes (ref. 3) and -146 to $-192 \mathrm{ppm}\left(\underline{\mathrm{vs}} \mathrm{H}_{3} \mathrm{PO}_{4}\right.$ ) for phosphirenes (ref.6). This parallelism between the ${ }^{29} \mathrm{Si}$ and $31 \mathrm{P}$ chemical shifts had already been noted in other instances (for example both ${ }^{29} \mathrm{Si}$ and ${ }^{31} \mathrm{P}$ resonances are shifted to low fields in 7-sila- and 7-phosphanorbornadienes, see ref. 22 and 23).

TABLE 1. Structural data on silirenes and phosphirenes $\mathrm{XC}_{2} \mathrm{R}_{2}^{\prime}$

\begin{tabular}{|c|c|c|c|}
\hline $\mathrm{x}$ & $\mathrm{SiR}_{2}$ & $\mathrm{P}-\mathrm{R}$ & $\mathrm{P}(\mathrm{R}) \longrightarrow \mathrm{W}(\mathrm{CO})_{5}$ \\
\hline $\mathrm{C}=\mathrm{C}(\AA)$ & 1.349 & 1.299 & 1.307 \\
\hline $\mathrm{C}-\mathrm{X}(\stackrel{\AA}{\mathrm{A}})$ (mean) & 1.820 & 1.820 & 1.789 \\
\hline$X-R(\AA)$ & 1.872 & 1.842 & 1.831 \\
\hline$\angle \operatorname{CXC}\left({ }^{\circ}\right)$ & 43.5 & 41.8 & 42.8 \\
\hline$\angle X C C\left(^{\circ}\right)($ mean $)$ & 68.2 & 69.1 & 68.5 \\
\hline$\angle \operatorname{CXR}\left({ }^{\circ}\right)$ (mean) & 120.6 & 104.2 & 107.6 \\
\hline Ref. & 17 & 18 & 7 \\
\hline
\end{tabular}

\section{CHEMICAL PROPERTIES}

The chemistry of silirenes has been investigated more completely than the chemistry of the recently discovered phosphirenes. As usual, the $\mathrm{Si}-\mathrm{C}$ bonds appear to be more reactive than the $\mathrm{P}-\mathrm{C}$ bonds. Hence, silirenes readily react with alcohols [ref. 1-4, 13-16] whereas phosphirenes are almost unreactive except under UV irradiation or when activating groups are bonded to the ring carbons [ref. 8] (eq. 9, 10).

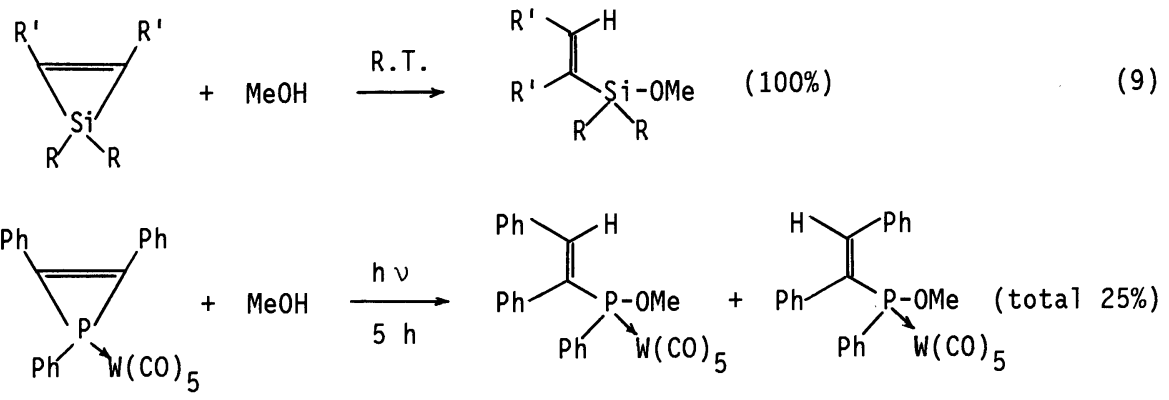

Similarly, numerous two-atom insertions have been described with silirenes (eq. 11).<smiles>[R]C1=CBBN([R])[Si]1([R])[R]</smiles>

(11) (ref. 24-26) $A=B: 0=C_{1}^{\prime},-N=C_{\backslash}^{\prime}, C_{C}=C_{\backslash}^{\prime},-C \equiv C-$ 
Generally, these reactions are carried out at R.T., under gentle heating or under UV irradiation. In other cases, the insertion is catalysed by nickel or palladium salts (ref. 14,27,28). The postulated mechanism involves the insertion of a zerovalent metallic moiety into the three-membered ring (eq. 12). Such an intermediate $(M=N i)$ has been characterized in solution very recently (ref. 39).<smiles>[R][R]1([R])C2([R])C3[R]C312</smiles>

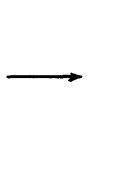

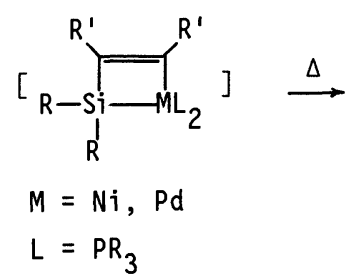<smiles>[R]C1=C([R])[Si]([R])([R])C([R])=C([R])[Si]1([R])[R]</smiles>

When no external reagent is available, this insertion product yields the corresponding 1,4disilacyclohexa-2,5-diene (ref. 29, 30). The picture is somewhat different with phosphirenes. In the absence of metallic catalyst, no insertion has been reported. The intermediate metallic insertion product can be isolated and has been characterized by X-ray crystal structure analysis in one case (ref. 31) (eq. 13).

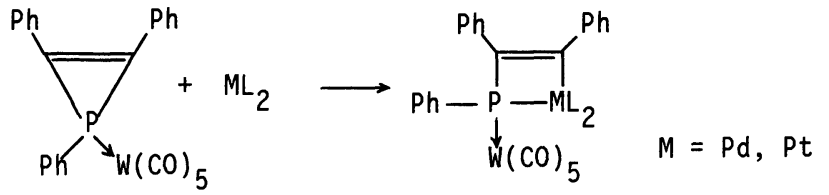

Its stability lowers its efficiency as a catalyst. However, two very peculiar insertion reactions have been discovered (ref. 32, 33) (eq. 14).

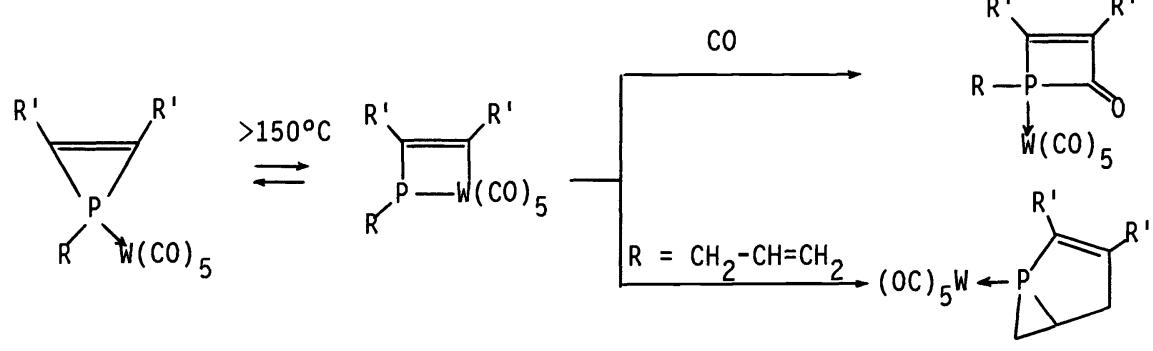

Apparently, CO insertion can also be achieved at much lower temperature in the coordination sphere of nickel. Another interesting reaction of silirenes is the silylene insertion (ref. 34) (eq. 15).<smiles>[R][Si]1([R])c2c1[c+]2[AsH2]</smiles>

This silylene insertion is one of the processes taking place upon thermal degradation of silirenes (ref. 35). A similar reaction has not yet been reported with phosphirenes but the reason may be simply that there is no efficient and neutral technique to generate phosphinidenes at moderate temperatures. Nevertheless, a formal insertion of phosphinidene has been achieved by an indirect route (ref. 36) (eq. 16).

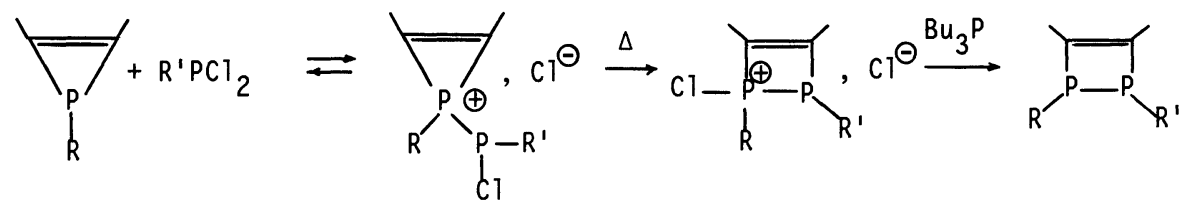

This scheme takes advantage of the presence of a lone pair at phosphorus. This lone pair, although rather unreactive, imparts several specific properties to phosphirenes. Some of them are detailed in eq. 17 (ref. 8). 


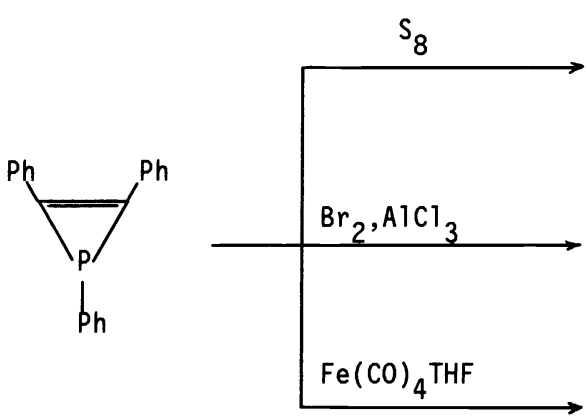

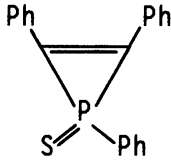

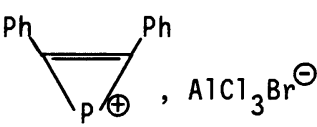

$\mathrm{PH} \backslash \mathrm{Br}$

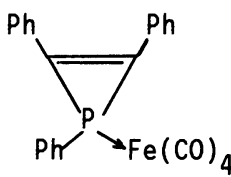

The pentavalent phosphirene derivatives are generally unstable and readily ring-open. Some other specific properties of phosphirenes are depicted in eq. 18, 19 (ref. 8).<smiles>C=C(C)C(=O)OCc1ccccc1</smiles>

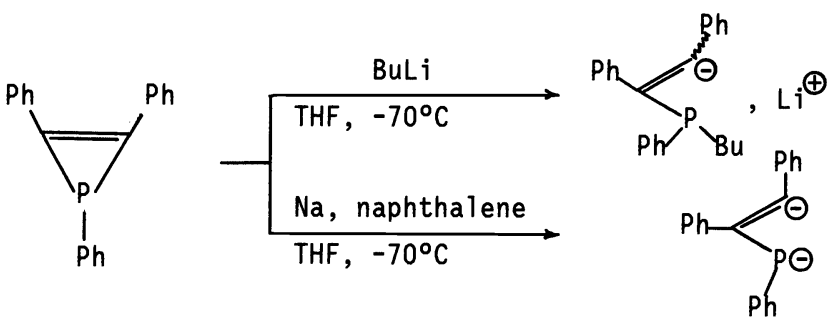

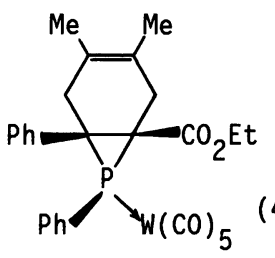

The Diels-Alder cycloaddition highlights the great thermal stability of phosphirene complexes and the weak cyclic delocalization of the ring. Before leaving phosphirenes and silirenes, one last question, concerning the potential aromaticity of silirenyl and phosphirenyl cations, deserves examination. According to theoretical calculations (ref. 37), silirenyl cations, if ever made, would not be aromatic. On the contrary, some indication exists that, when suppressing the destabilizing $\mathrm{n} \pi$ interaction by $\mathrm{P}$-complexation, the phosphirenyl cation benefits from some extra-stabilization by cyclic delocalization (ref. 38) (eq. 20).

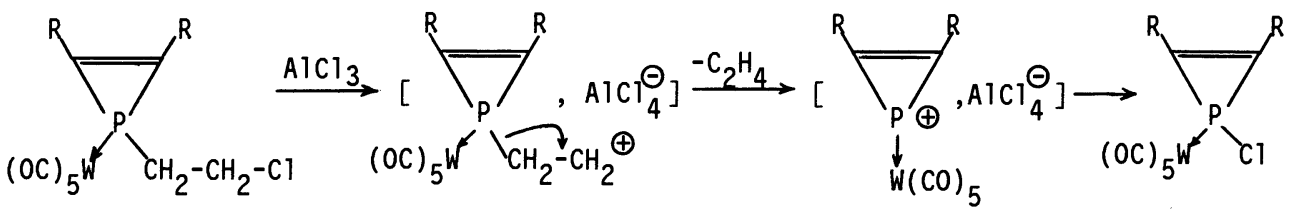

\section{REFERENCES}

1) R.T. Conlin and P.P. Gaspar, J. Am. Chem. Soc. 98, 3715-3716 (1976)

2) D. Seyferth, D.C. Annarelli and S.C. Vick, J. Am. Chem. Soc. 98, 6382-6384 (1976)

3) D. Seyferth, D.C. Annarelli and S.C. Vick, J. Organometal. Chem. 272, 123-139 (1984)

4) M. Ishikawa, K.-I. Nakagawa and M. Kumada, J. Organometal. Chem. $\frac{131}{13}$, C15-C20 (1977); $190,117-128(1980)$

5) K.S. Fongers, H. Hogeveen and R.F. Kingma, Tetrahedron Lett. 24, 643-646 (1983)

6) S. Lochschmidt, F. Mathey and A. Schmidpeter, Tetrahedron Lett. 27, 2635-2638 (1986)

7) A. Marinetti, F. Mathey, J. Fischer and A. Mitschler, J. Am. Chem. Soc. 104, 4484-4485 (1982)

8) A. Marinetti and F. Mathey, J. Am. Chem. Soc. 107, 4700-4706 (1985) 
9) F. Mercier and F. Mathey, Tetrahedron Lett. 27, 1323-1326 (1986)

10) A. Marinetti-Mignani and R. West, Organometa11ics $\underline{6}, 141-144$ (1987)

11) D. Gonbeau, G. Pfister-Guillouzo, A. Marinetti and F. Mathey, Inorg. Chem. 24, 4133-4140 (1985)

12) A. Marinetti, C. Charrier, F. Mathey and J. Fischer, Organometallics 4, 2134-2138 (1985)

13) M. Ishikawa, T. Fuchikami and M. Kumada, J. Am. Chem. Soc. 99, 245-247 (1977)

14) H. Sakurai, Y. Kamiyama and Y. Nakadaira, J. Am. Chem. Soc. 99, 3879-3880 (1977)

15) M. Ishikawa, K. Nishimura, H. Sugisawa and M. Kumada, J. Organometal. Chem. 194, 147-158 (1980)

16) M. Ishikawa, H. Sugisawa, T. Fuchikami, M. Kumada, T. Yamabe, H. Kawakami, K. Fukui, Y. Ueki and H. Shizuka, J. Am. Chem. Soc. 104, 2872-2878 (1982)

17) K. Hirotsu, T. Higuchi, M. Ishikawa, H. Sugisawa and M. Kumada, J. Chem. Soc., Chem. Commun., 726-727 (1982)

18) A. Marinetti, F. Mathey, J. Fischer and A. Mitschler, J. Chem. Soc., Chem. Commun., 45-46 (1984)

19) D. Gonbeau and G. Pfister-Guillouzo, Nouv. J. Chim. 9, 71-73 (1985)

20) J.-C. Barthelat, G. Trinquier and G. Bertrand, J. Am. Chem. Soc. 101, 3785-3789 (1979)

21) P.R. Jones and D.D. White, J. Organometal. Chem. 154, C33-C36 (1978)

22) A. Marinetti, F. Mathey, J. Fischer and A. Mitschler, J. Chem. Soc., Chem. Commun., 667-668 (1982)

23) H. Sakurai, Y. Nakadaira, T. Koyama and H. Sakaba, Chem. Lett., 213-216 (1983)

24) D. Seyferth, D.P. Duncan and S.C. Vick, J. Organometal. Chem. 125, C5-C10 (1977)

25) D. Seyferth, S.C. Vick, M.L. Shannon, T.F.0. Lim and D.P. Duncan, J. Organometal. Chem. 135, C37-C44 (1977)

26) D. Seyferth, S.C. Vick and M.L. Shannon, Organometa1lics 3, 1897-1905 (1984)

27) D. Seyferth, M.L. Shannon, S.C. Vick and T.F.O. Lim, Organometallics 4, 57-62 (1985)

28) M. Ishikawa, S. Matsuzawa, T. Higuchi, S. Kamitori and K. Hirotsu, Organometallics 4 , 2040-2046 (1985)

29) M. Ishikawa, J. Fuchikami and M. Kumada, J. Chem. Soc., Chem. Commun., 352 (1977)

30) M. Ishikawa, H. Sugisawa, M. Kumada, T. Higuchi, K. Matsui and K. Hirotsu, Organometallics 1, 1473-1477 (1982)

31) D. Carmichael, P.B. Hitchcock, J.F. Nixon, F. Mathey and A. Pidcock, J. Chem. Soc., Chem. Commun., 762-763 (1986)

32) A. Marinetti, J. Fischer and F. Mathey, J. Am. Chem. Soc. 107, 5001-5002 (1985)

33) J. Svara, A. Marinetti and F. Mathey, Organometallics 5, 1161-1167 (1986)

34) D. Seyferth and S.C. Vick, J. Organometa1. Chem. 125, C11-C17 (1977)

35) M. Ishikawa, H. Sugisawa, M. Kumada, H. Kawakami and T. Yamabe, Organometallics 2 , 974-979 (1983)

36) L. Ricard, N. Maigrot, C. Charrier and F. Mathey, Angew. Chem., Int. Ed. Eng1. 26 (1987)

37) M.S. Gordon, P. Boudjouk and F. Anwari, J. Am. Chem. Soc. 105, 4972-4976 (1983)

38) B. Deschamps and F. Mathey, Tetrahedron Lett. 26, 4595-4598 (1985)

39) M. Ishikawa, J. Ohshita, Y. Ito and J. Iyoda, J. Am. Chem. Soc. 108, 7417-7419 (1986) 